\title{
Capital Structure Determinants of SME Shari'ah Compliant Companies
}

\author{
Mazila Md-Yusuf ${ }^{1}$ \\ ${ }^{1}$ Arshad Ayub Graduate Business School, Universiti Teknologi MARA \\ Email: mazila370@salam.uitm.edu.my
}

\begin{abstract}
Capital structure implies the components of capital in a company and has implications on the total financing cost of a company. This study examines the capital structure of Malaysian Small and Medium Enterprise (SME) shari'ah compliant companies that are listed in the Bursa Malaysia. The aim of the study is to identify the factors and the relationship of these factors with the capital structure of the SME shari'ah compliant companies. In this study, 18 SME shari'ah compliant companies were examined from the period of 2005 until 2014. Capital structure was proxied by debt ratio and the determinant variables used in this study were age of firm, firm's asset tangibility, firm's liquidity, firm's profitability, firm's growth rate and firm's taxation payment. The pooled ordinary least square (POLS) multiple regression estimation was used and the findings showed that age of firm, firm's asset tangibility and firm's liquidity are the determinants that influenced the capital structure of the SME shari'ah compliant companies. The results also indicated that there is a positive correlation between debt ratio of SME shari'ah compliant companies listed in the Bursa Malaysia. On the other hand, there is a negative correlation between firm's asset tangibility, firm's growth rate and firm's taxation payment and debt ratio.
\end{abstract}

Keywords: capital structure, capital structure theories, leverage, SMEs, shari'ah compliant companies

\section{Introduction}

Capital structure is the components of capital that firms use in conducting their operations. Basically, there are two types of capital: debt and equity capital. Equity capital refers to share that represent an ownership of a company by the shareholders, while debt capital refers to any long-term borrowed money from financial and non-financial institutions. Due to its function which will affect the company's value, capital structure decision is crucial on the company's financial decision making. Selecting the precise combination of debt and equity is not easy. In lieu of that, capital structure is always referred to as leverage of the company. Poor leverage decision can result in high cost of financing of the company, while effective decision of leverage can lower the cost of financing.

One of the sectors that contributed to the growth and employment in developed and developing countries is the small and medium enterprises (SME) sector. The SME companies are considered to be the engines of growth in Malaysia's economy. Since 2004, value added growth of SMEs in Malaysia have consistently outperformed that of the overall GDP growth. 
Most of the time SME companies use equity as their sources of financing. However, in certain economic conditions, the usage of leverage of debt capital is better than equity capital. Thus, it is important for SME companies to understand the factors affecting their total cost of financing in order to make an effective capital structure decision. This is because wrong decision-making in choosing the capital will lead to financial distress and bankruptcy of the company.

This study aimed to determine the factors that would affect the leverage or debt level of the SME shari'ah compliant companies in order for them to make effective capital structure decision. Many past researches were not found to be done on capital structure of SME companies that focusing on shari'ah compliant companies. Therefore, this study attempted to determine the factors and the relationship of these factors with the debt ratio of the SME shari'ah compliant companies listed in the Bursa Malaysia.

The remainder of this paper is divided into five sections. Section 2 contains a brief overview of the literature. Section 3 discusses the methodology involved, followed by the results of the study (Section 4) and discussion of the findings (Section 5). Section 6 concludes the study.

\section{Literature Review}

\subsection{Capital Structure Theories}

There are several theories of capital structure. The traditional theories stated that using leverage could increase the value or lower the cost of capital of a firm. Modigliani \& Miller (1958) looked at capital structure in a very basic world where they postulated that capital structure and financing decisions affect neither cost of capital nor market value of a firm. The trade-off capital structure theory stated that the optimal debt ratio is set by balancing the trade-off between the tax advantage when firm borrows and the bankruptcy cost that firm might be facing.

According to the theory, an increase in the debt level causes an increase in bankruptcy, financial distress and agency costs, and these would decrease the firm's value. Therefore, the optimal capital structure would be achieved when the marginal present value of the financial distress and bankruptcy costs on additional debt is equal to the marginal present value of the tax shield on additional debt (Jensen \& Meckling, 1976); Myers, 1977). According to pecking order theory, companies normally prioritize their ways of financing starting with using the internal funds, followed with debt and lastly with new equity (Myers \& Majluf, 1984). The theory suggests that highly profitable companies tend to use internal funding, whereas low profitability companies tend to use external financing.

\subsection{Capital Structure Measurement}

Capital structure refers to the components of debt and equity that companies use to finance their business operations. Therefore, the vital division in capital structure is between the usage of debt and equity financing in a company. In the studies of capital structure, leverage or debt ratio is commonly used as a proxy for the capital structure, examples are in Baharuddin et al. (2011), Sheikh \& Wang (2011), Ba-Abbad \& Ahmad-Zaluki (2012) and Md-Yusuf, Yunus, \& Supaat (2013). The debt ratio is calculated as the total debt divided by total assets. 


\subsection{Capital Structure Determinants and Empirical Evidence}

Previous studies have investigated the validity of the theories of capital structure. In these studies, capital structure, proxied by debt ratio, is said to be related to the internal factors such as age of firm, firm's asset tangibility, firm's liquidity, firm's profitability, firm's growth rate and firm's taxation payment. These factors are briefly explained below.

\subsubsection{Age of Firm}

Age of firm refers to the number of years that companies are in business. Basically, the sources of funding rely on whether a company is in the maturing or developing stage. According to the trade-off theory, age of firm is positively correlated with debt ratio. Companies that existed for long period of years have better access to borrowing because they have established strong relationship with lenders that normally keep track of their financial reputation and record. However, according to the pecking order theory, older companies are able to build up substantial amount of retained earnings. Thus, they do not need to seek external funding and therefore, age of firm has negative relation with debt level. Most studies in the past found negative relation between age of firm and debt ratio (see Viviani, 2008; Saarani \& Shahadan, 2013; Forte, Barros \& Nakamura, 2013; Handoo \& Sharma, 2014).

\subsubsection{Firm's Asset Tangibility}

Firm's assets tangibility refers to assets which are suitable to be used as collateral for loans and also considered as stability measurement of a company, because when company is in need of cash requirement circumstances, these assets can be liquidated and converted into cash. Hence, a company with lesser tangible assets may have higher risk of bankruptcy. According to the trade-off theory, there is a positive relation between tangible assets and leverage level, since tangible assets can serve as security for debt financing. However, according to the pecking-order theory, there is a negative relation between assets tangibility and debt level since firms that owned more fixed assets tend to depend on equity financing. Example of past studies that found positive relation is Baharuddin et al. (2011) and Md-Yusuf et al. (2013), while Saarani \& Shahadan (2013) and Forte et al. (2013) found negative relation between assets tangibility and debt level.

\subsubsection{Firm's Liquidity}

Firm's liquidity refers to the firm's ability to transform assets into cash easily without affecting the asset's price. Firm that has much liquid assets able to pursue attractive future investment opportunities using its internal funding without the need to adjust its basic capital structure. Since companies with higher liquidity ratios are able to meet their contractual obligations on time, theoretically, the trade-off theory suggests that these companies should borrow more. Thus, this theory states a positive relation between liquidity and leverage level. Meanwhile, the pecking order theory states a negative relation between liquidity and debt ratio because a firm that is liquid prefers to use internal capital in funding new investments. Some empirical studies that supported the pecking order hypothesis are Viviani (2008), Sbeiti (2010) and Afza \& Hussain (2011). 


\subsubsection{Firm's Profitability}

Firm's profitability is defined as the firm's capability to make profit. According to pecking order theory, profitability has a negative relation with leverage level since profitable company does not need to borrow much since it can do most of its financing with retained earnings. This contradicts with the trade-off theory which stated that a profitable company should have more debt because of the borrowing power and loan obligation payment ability. In this case, capital structure is said to have a positive relation with profitability. Some studies on the relationship between profitability and debt ratio are Forte et al. (2013), Saarani \& Shahadan (2013) and Handoo \& Sharma (2014).

\subsubsection{Firm's Growth Rate}

Based on the trade-off theory, firm's growth rate has a negative relation with capital structure because firm's growth is measured by looking into the intangible assets that a company holds. A company that has higher intangible assets tends to borrow less than a company that has more tangible assets. However, pecking order theory states that there is a positive relation between firm's growth rate and capital structure since high growth rate firm prefers debt than equity to finance new investments opportunities. Some empirical studies have confirmed the relationship between firm's growth rate and leverage ratio (see Baharuddin et al., 2011; Proenca, Laureano \& Laureano, 2014).

\subsubsection{Firm's Taxation Payment}

Firm's taxation payment refers to amount of taxes that levied on companies by the government. Tax deductible expenses such as interest can reduce the amount of tax payments. A firm that has higher corporate tax rate would be at an advantage when using debt financing. According to Modigliani \& Miller (1963), due to the tax-deductible association with interest payments on debt, firm would prefer debt financing rather than equity financing. The trade-off theory states that capital structure has a positive relation with firm's taxation payment. Some empirical studies are Saarani \& Shahadan (2013) and Handoo \& Sharma (2014).

\section{Research Methodology}

As of 2014, there are 667 shari'ah compliant companies listed in Bursa Malaysia. However, in this study, the focused is on the SME shari'ah compliant companies that have won the Enterprise 50 (E50) award. There are 31 companies that fulfilled the criteria, but our sample is reduced to only 18 SME shari'ah compliant companies due to the 10 years data availability. Our data set comes from the annually financial statements of the 18 SME shari'ah compliant companies for the period of 2005 through 2014. The data were collected from Data stream database system.

The debt ratio is used as a proxy for the capital structure of the SME shari'ah compliant companies. The debt ratio is calculated as total debt divided by total assets. The six independent variables are specified as follows: age of firm is defined as number of years companies in business; firm's asset tangibility is calculated as total fixed assets to total assets; firm's liquidity is referred to as current assets divided by current liabilities; firm's profitability is calculated as income before interest and tax divided by total assets; firm's growth rate is defined as intangible assets divided by total assets and firm's taxation payment referred to as 
tax expenses divided by earnings before tax. In this study, the pooled ordinary least squares (POLS) estimations model was employed. The estimation model is as follows:

$$
\begin{gathered}
D R_{i t}=\beta_{0}+\beta_{1} A G E_{i t}+\beta_{2} T A N G_{i t}+\beta_{3} L I Q_{i t}+\beta_{4} P R O F_{i t}+\beta_{5} G R O W_{i t}+ \\
\beta_{6} T A X_{i t}+\varepsilon_{i t}
\end{gathered}
$$

Where:

$\begin{array}{ll}D R_{i t} & : \text { debt ratio of firm } \mathrm{i} \text { at time } \mathrm{t} \\ A G E_{i t} & \text { : age of firm } \mathrm{i} \text { at time } \mathrm{t} \\ T A N G_{i t} & : \text { firm's asset tangibility of firm } \mathrm{i} \text { at time } \mathrm{t} \\ L I Q_{i t} & \text { : firm's liquidity of firm } \mathrm{i} \text { at time } \mathrm{t} \\ P R O F_{i t} & \text { : firm's profitability of firm } \mathrm{i} \text { at time } \mathrm{t} \\ G R O W_{i t} & \text { : firm's growth rate of firm } \mathrm{i} \text { at time } \mathrm{t} \\ T A X_{i t} & \text { : firm's taxation payment of firm } \mathrm{i} \text { at time } \mathrm{t} \\ \varepsilon_{i t} & \text { : stochastic error term of firm } \mathrm{i} \text { at time } \mathrm{t}\end{array}$

\section{Results and Discusion}

The descriptive statistics of the variables used in this study are presented in Table 1 and the POLS regression results are shown in Table 2. On average, it showed that the SME shari'ah compliant companies were funded by equity financing rather than debt financing during the period of the study since the mean of the debt ratio is $16.27 \%$. The companies have been in business for at least 18 years and total assets of $40.83 \%$ in the form of tangible assets. In terms of liquidity, on average, the SME shari'ah compliant companies can cover 2.3 times their short-term obligations and also able to make $6.65 \%$ profit. In terms of growth, on average, the companies were growing at $15.74 \%$ and out of the profits, $10.88 \%$ were paid as tax expenses.

Table 1: Descriptive Statistics Results

\begin{tabular}{llllllll}
\hline & DR & AGE & TANG & LIQ & PROF & GROW & TAX \\
\hline Mean & 0.1627 & 18.2778 & 0.4083 & 2.3449 & 0.0665 & 1.5741 & 0.1088 \\
\hline Median & 0.1021 & 17.5000 & 0.4399 & 1.6887 & 0.0680 & 0.0076 & 0.1028 \\
\hline Maximum & 0.5126 & 37.0000 & 0.7763 & 17.6380 & 0.3464 & 43.7159 & 2.8072 \\
\hline Minimum & 0.0000 & 1.0000 & 0.0398 & 0.3869 & -0.2823 & -0.0312 & -0.9412 \\
\hline Std. Dev. & 0.1499 & 9.5940 & 0.1804 & 2.3760 & 0.0941 & 7.6741 & 0.3347 \\
\hline
\end{tabular}

Table 2: POLS Regression Result

\begin{tabular}{lllll}
\hline Variable & Coefficient & Std error & T-statistic & Prob \\
\hline C & 0.263 & 0.044 & 5.950 & 0.000 \\
\hline Age of Firm & -0.040 & 0.014 & -2.841 & 0.005 \\
\hline Firm's Asset Tangibility & 0.203 & 0.055 & 3.688 & 0.000 \\
\hline Firm's Liquidity & -0.033 & 0.004 & -8.205 & 0.000 \\
\hline Firm's Profitability & -0.041 & 0.097 & -0.422 & 0.673 \\
\hline Firm's Growth Rate & 0.002 & 0.001 & 1.831 & 0.069 \\
\hline Firm's Taxation Payment & 0.020 & 0.029 & 0.688 & 0.500 \\
\hline
\end{tabular}


Referring to Table 2, the results showed that age of firm is negatively correlated with debt ratio which is consistent with the pecking order theory. It implies that the older the SME companies, the lower will be their leverage level due to the fact that these companies used more internal financing. This is true since they are shari'ah compliant companies, therefore they might limit their borrowing capital. Age of the firm is significant and thus is a factor in explaining the changes in the debt ratio of the SME shari'ah compliant companies listed in Bursa Malaysia. Example of past studies that found a negative relation between age of the firm and debt level is studies done by Forte et al. (2013) and Saarani \& Shahadan (2013).

In this study, the findings showed that firm's asset tangibility has a positive relation with leverage level. This is in line with all capital structure theories. It is obvious that a company that has more tangible assets than intangible assets able to borrow more loans because the tangible assets could be used as securities and collateral for the loans. In addition, the results showed that firm's asset tangibility is a significant factor in determining the capital structure. It means that the SME companies that have more tangible assets used debt in funding their operations. Similar results were found by Baharuddin et al. (2011), Md-Yusuf et al. (2013) and Saarani \& Shahadan (2013).

As shown in Table 2, firm's liquidity has a negative relation with debt ratio which implies that an increase in firm's liquidity would reduce the amount of borrowing of the SME companies. The findings indicate that the SME companies prefer to liquidate their assets rather than borrowing if they are in need of cash. The results seem to be consistent with the pecking order theory. In this study, firm's liquidity is also considered as one of the determinants of capital structure in SME shari'ah compliant companies in Malaysia. Past studies that found a negative relation between firm's liquidity and debt level are Mazur (2007), Viviani (2008), Sbeiti (2010) and Md-Yusuf et al. (2013).

In Table 2, the findings indicated a negative relation between firm's profitability and debt ratio. The negative relation between firm's profitability and debt ratio implies that companies would retain their profits and would use them in the future to finance their operations instead of borrowing from banks, unless the internal funding is insufficient. The result does not support the trade-off theory but is consistent with the pecking order theory. However, in this study, firm's profitability as the determinants of the debt level of SME shari'ah compliant companies listed Bursa Malaysia is insignificant.

The findings in Table 2 showed that firm's growth rate has a positive relation with debt ratio. According to pecking order theory, capital structure has a positive relation with firm's growth. High growth firm normally has insufficient funds to meet its operation needs, and thus need to borrow in order to meet new investments. However, the findings of this study showed that firm's growth rate is an insignificant factor in influencing the leverage level of the SME shari'ah compliant companies. This shows that growth of a company is not important in deciding whether to use equity or debt to finance the company.

As stated in Table 2, the results of the study showed that firm's taxation payment has a positive relation with capital structure, which is consistent with the trade-off theory. However, firm's taxation payment is found to be an insignificant factor in determining the leverage ratio of SME shari'ah compliant companies Malaysia. It implies that the benefit of the benefitting from the debt tax shields is not important in deciding the types of capital to be used by the firms. 


\section{Conclusion}

This study findings show that there is a positive relation between leverage level with firm's assets tangibility, firm's growth rate and firm's taxation payment. Moreover, the results show a negative relation between debt ratio with age of firm, firm's liquidity and firm's profitability. This study also found that age of firm, firm's asset tangibility and firm's liquidity are the determinants of the capital structure in the SME shari'ah compliant companies listed in the Bursa Malaysia, while firm's profitability, firm's growth rate and firm's taxation payment are not the determinants. Therefore, it could be concluded that the longer the companies have been in the business and having more tangible assets and higher liquidity would make them use more debt compared to equity as their financing alternatives. The reason could be due to the lower risk associated with the companies since the companies could easily convert their assets into cash if the needs really require them to do so.

\section{Acknowledgements}

Appreciation goes to Nur Fatiha Ahmad Khusaini who has made contributions in the data collections of this study.

\section{References}

Afza, T., \& Hussain, A. (2011). Determinants of Capital Structure Across Selected Manufacturing Sectors of Pakistan. International Journal of Humanities and Social Science, vol.1 No.12.

Baharuddin, N. S., Khamis, Z., Mahmood, W. M., \& Dollah, H. (2011). Determinants of Capital Structure for Listed Construction Companies in Malaysia. Journal of Applied Finance \& Banking, vol.1, no.2, pp 115-132.

Ba-Abbad, K. and Ahmad-Zaluki, N.A. (2012). The Determinants of Capital Structure of Qatari Listed Companies. International Journal of Academic Research in Accounting, Finance and Management Sciences, vol. 2, no. 2, pp. 93-108, 2012.

Forte, D., Barros, L. A., \& Nakamura, W. T. (2013). Determinants of the Capital Structure of Small and Medium Sized Brazilian Enterprises. Brazilian Administration Review, pp. 347-369.

Handoo, A., \& Sharma, K. (2014). A Study on Determinants of Capital Structure in India. IIMB Management Review, vol.26, pp. 170-182.

Hijazi, S. T., \& Tariq, Y. B. (2006). Determinants of Capital Structure: A Case for Pakistani Cement Industry. Lahore Journal of Economics, vol. 11, No. 1, pp. 63-80.

Jensen, M. C., \& Meckling, W. H. (1976). Theory of The Firm: Managerial Behavior, Agency Costs and Ownership Structure. Journal of Financial Economics, Vol.3 No.4 pp.305360 . 
Mazur, K. (2007). The Determinants of Capital Structure Choice: Evidence From Polish Companies. International Advances in Economic Research, vol.13, pp. 495-514.

Md-Yusuf, M., Yunus, F. M., \& Supaat, N. Z. (2013). Determinants of Capital Structure in Malaysia Electrical and Electronic Sector. World Academy of Science, Eginnering and Technology, pp. 1032-1037.

Modigliani, F., \& Miller, M. H. (1958). The Cost of Capital, Corporation Finance and the Theory of Investment. The American Economic Review, vol. 48, No. 3, pp. 261-297.

Myers, S. C. (1977). Determinants of Corporate Borowing. Journal of Financial Economics, vol. 5, pp. 147-175.

Myers, S. C., \& Majluf, N. S. (1984). Corporate Financing and Investment Decision When Firms Have Information That Investor Do Not Have. Journal of Financial Economics, vol.13 No.2, pp. 187-221.

Proenca, P., Laureano, R. M., \& Laureano, L. M. (2014). Determinants of Capital Structure and The 2008 Financial Crisis: Evidence From Portuguese SMEs. Procedia - Social and Behavioral Sciences, vol.13 pp.182 - 191.

Saarani, A. N., \& Shahadan, F. (2013). The Determinant of Capital Structure of SMEs in Malaysia: Evidence from Enterprise 50 (E50) SMEs. Asian Social Science, vol. 9, No. 6, pp. 64-73.

Sbeiti, W. (2010). The Determinants of Capital Structure an Empirical Study of Firms in Manufacturing Industry in Pakistan. Managerial Finance, pp. 117-133.

Sheikh, N. A., \& Wang, Z. (2011). Determinants of Capital Structure: An Empirical Study of Firms in Manufacturing Industry of Pakistan. Managerial Finance, vol. 37 Iss: 2, pp.117 $-133$.

Viviani, J.-L. (2008). Capital Structure Determinants: An Empirical Study of French Companies in The Wine Industry. International Journal of Wine Business Research, vol. 20, 2, pp. $171-194$. 